\title{
Human Origins and Evolution: Cold Spring Harbor, Déjà Vu
}

\author{
T.D. WHITE \\ Department of Integrative Biology, and Human Evolution Research Center, \\ University of California, Berkeley, California 94720 \\ Correspondence: timwhite@berkeley.edu
}

\begin{abstract}
The Cold Spring Harbor Symposia of the 1950s were key to integrating human evolutionary studies into biology. That integration provided a solid foundation for systematic and functional interpretations of an expanding base of fossil and molecular evidence during the latter half of the 20th century. Today, the paleontological record of human evolution amassed during the last 150 years illuminates the human clade on life's tree. However, the rise of Hennegian parsimony cladistics and punctuationalism during the end of the last century witnessed the partial abandonment of classificatory conventions cemented by Mayr, Simpson, Dobzhansky, and others at Cold Spring Harbor. This has led to an artificial, postmillennial amplification of apparent species diversity in the hominid clade. Work on a stratigraphically thick and temporally deep sedimentary sequence in the Middle Awash study area of Ethiopia's Afar Depression reveals an assembly order of hominid anatomies and behaviors that was impossible for Darwin to discern. Large parts of that record appear to reflect phyletic evolution, consistent with the lessons and expectations of Cold Spring Harbor in 1950. Molecular biology cannot reveal the assembly sequences or contexts of human origins and evolution without reference to adequate geological, geochronological, paleobiological, and archaeological records. Today's consilience of these disparate data sets would have impressed Charles Darwin.
\end{abstract}

Darwin would have been astonished and delighted to witness the 2009 Cold Spring Harbor (CSH) Laboratory's Symposium on Quantitative Biology anniversary celebrations of his birth and book. He would have recognized the many persistent themes we discussed, taken satisfaction in the hundreds of mechanisms revealed, and been amazed by the broad advancing front of modern evolutionary biology. From "shadow" enhancers (Hong et al. 2008) to segmental duplications (Marques-Bonet et al. 2009) and from ancient fossils to the "cognitive niche" (Pinker 2003), ours is a world full of insights unavailable to Darwin in 1859.

In his historical scientist mode, Darwin was directly concerned with the paleontological, neontological, and contextual data resulting from the natural, one-time, uncontrolled experiment of life on earth. Darwin clearly understood how the rich data sources of the neontological realm were living products of that vast experiment. And the phylogenetic and functional elucidation of how extant diversity has arisen - now provided by the modern landscape of molecular biology - is truly astonishing, even in the hindsight of a single decade. These revelations make it too easy to forget what Darwin clearly appreciatedthat the historical record of fossils, artifacts, and contexts is crucial to the fullest understanding of our evolution. The organizers of this Symposium deserve congratulations for recognizing this fact and for welcoming a broad community to join the celebration.

I am not a historian of science, but the opportunity to participate in the Symposium provides an opportunity to highlight the important historical role that earlier gatherings at the Cold Spring Harbor Laboratory had in the development of human evolutionary studies. Celebrations here in 1950 and 1959 cemented major elements of the modern synthesis and also served to catalyze the integra- tion of human evolutionary studies into modern biology. The integration came with important lessons sometimes lost on modern practitioners.

Human evolution was touched upon ever so lightly in Darwin's 1859 On the Origin of Species that we celebrate this year. There, Darwin devoted detailed attention to "Imperfections in the Geological Record," perhaps because he saw such gaps as rendering his theory vulnerable to critics (Sepkoski and Ruse 2009). His 1871 treatise on human evolution pondered what was then one of the largest imperfections of earth's historical record - the paucity of truly early hominid fossil remains (family Hominidae bounds genera in the human clade after the last common ancestor we shared with chimpanzees). We have come a long way. I review this progress, discuss the impacts of the 1950 and 1959 CSH Symposia, and illustrate current investigations of hominid evolution by using examples from earth's most important repository of data on human origins and evolution, Ethiopia's Afar Depression.

\section{DARWIN ON HOMINIDS}

Living humans are obviously anatomically, physiologically, and behaviorally uniquely different from our closest living relatives, the African apes. What was the sequence by which natural selection assembled our obvious derivations of brain expansion, canine reduction, technology, and bipedality?

Darwin famously avoided these topics in 1859, but despite this, Origin's implications for human evolution could scarcely be concealed. Indeed, they generated even more immediate discussion and debate than did his later (1871) treatise on humans (Browne 2002). When Huxley wrote on the subject in 1863-followed by Darwin in 
1871 - the poverty of the human paleontological record was overwhelming. Darwinian scholars had only a small, mostly European paleontological record (extracted primarily from archaeological contexts) with which to address the question of human origins and evolution. A handful of western European Neanderthals had been labeled everything from ancestral to pathological. Even the extant great apes were barely known. So Darwin and Huxley turned to the extant hominoid primates to serve as their "outgroup" for humans and as proxies for the common ancestors we once shared with these now relict forms.

The late Stephen J. Gould famously characterized hominid paleontology as follows: “...no true consensus exists in this most contentious of all scientific professions... a field that features more minds at work than bones to study" (Gould 2002, p. 910). Hominoid primates are, in general, highly variable as judged by any of their living representatives. All workers agree that there is rampant homoplasy within the clade. Hominids have always lived fairly high on the food chain. Relative to many other mammals, they are $\mathrm{K}$-selected, and therefore rare as fossils. These factors all contribute to make the delineation of hominid species lineages very difficult... and contentious. Contention is difficult to quantify, but given the literally thousands of hominid fossils - and the relatively few professionals who work to interpret them-Gould's characterization has surely been invalid since early in the 20th century. The fossil samples are today relatively large, even though the hominid clade's record is terrestrial and therefore still full of imperfections.

\section{HOMINIDS APLENTY: 1900-1950}

The hominid fossil record was pushed deep into the Pleistocene by Eugene Dubois' discovery of Pithecanthropus (now Homo) erectus on Java near the end of the 18 th century. In less than a decade, recovery of a large sample of Neanderthals in Croatia would barely precede the extraction of even more complete remains from France and elsewhere. By 1925, Raymond Dart had recognized Australopithecus from Pliocene antiquity in South Africa. By 1938, Robert Broom had recognized what he called Paranthropus (now Australopithecus) robustus.

Decades would pass before Australopithecus was afforded hominid status. Until the advent of radioisotopic dating decades later, the age of all of these discoveries remained largely in the realm of informed speculation. As time's veil was lifted progressively from younger to older, arguments about the place of these various fossils on the family tree ran the gamut from unilineal to speciose. There was even a joker in the deck, in the form of the Piltdown forgery. Different schools of thought arose, practitioners of human evolutionary studies came increasingly from anthropology rather than anatomy (Delisle 2006; White 2009), but the popular appeal of the quest to understand human evolution persisted.

\section{HOMINIDS IN THE MODERN SYNTHESIS}

The integration of 19 th century selection theory with Mendelian and population genetics was labeled the "mod- ern synthesis" by Julian Huxley (Huxley 1942). Key among its architects were Mayr, Simpson, and Dobzhansky. All of them grappled with the hominid fossil record and all were present at the $1950 \mathrm{CSH}$ Symposium. Dobzhansky had turned his attention to human evolution in 1944. In tune with Simpson, he recognized both "horizontal" and "vertical" species (the latter are "chronospecies" that constitute arbitrary divisions of species lineages): "In practice, the incompleteness of the geological record is made use of in making "vertical" classifications: the gaps in the fossil series subdivide the continuous succession of forms into discrete sections" (Dobzhansky 1944, p. 256). Gaps became an ally instead of a problem. Dobzhansky even diagnosed Piltdown correctly: “...it now seems fairly clear that these remains are a mixture of ape and human bone fragments" (1944, p. 257). Hominid classification did not escape his attention: "The abuse of generic and specific names by students of the hominid evolution is notorious; it is making this fascinating field rather bewildering to other biologists" (1944, p. 257). And on the matter of phylogeny, Dobzhansky outlined the null hypothesis (following earlier writers such as Schwalbe and Weidenreich in this regard) as follows: “... as far as known, no more than a single hominid species existed at any one time level.” (1944, p. 261).

\section{THE 1950 CSH SYMPOSIUM}

In June of 1950, the 9-day symposium "Origin and Evolution of Man" was held at the Biological Laboratory, Cold Spring Harbor. The program was worked out in cooperation between Dobzhansky and anthropologist Sherwood Washburn. The 129 registered participants included prominent anthropologists (A. Kroeber, E. Hooton, W. Howells, C. Coon, W. Pollitzer, A. Schultz, T. Stewart) and geneticists (B. Glass, E. Hunt, J. Neel, J. Spuhler, C. Stern), as well as E. Mayr and G. Simpson (Fig. 1).

As Browne notes, by this time in the mid 20th century, the modern synthesis "...had almost taken the form of a political treaty" (Browne 2008, p. 324). The CSH Symposium created a historically pivotal intersection for the architects of that synthesis and the anthropological community, whose practitioners had been slow on the uptake, but who would (mostly) promptly assimilate two key concepts that Dobzhansky had already chastised them for ignoring in his 1944 paper: populational thinking within an evolutionary species concept, and the classification that went along with it. As Mayr would later write of the CSH 1950 gathering, "It was on that occasion that the study of fossil man was integrated into the evolutionary snythesis [sic]" (Mayr 1982, p. 231).

In his 1944 paper, Dobzhansky had written, "The time is not far past when many systematists designated as species any two populations which they could (or thought that they could) distinguish by examining the morphology of a single specimen... . Lately such extravagances are becoming rare, but conservative systematists still cling to a purely morphological species concept." Adolph Schultz was an anatomist not widely associated with the modern synthesis, but his contribution to the $1950 \mathrm{CSH}$ 

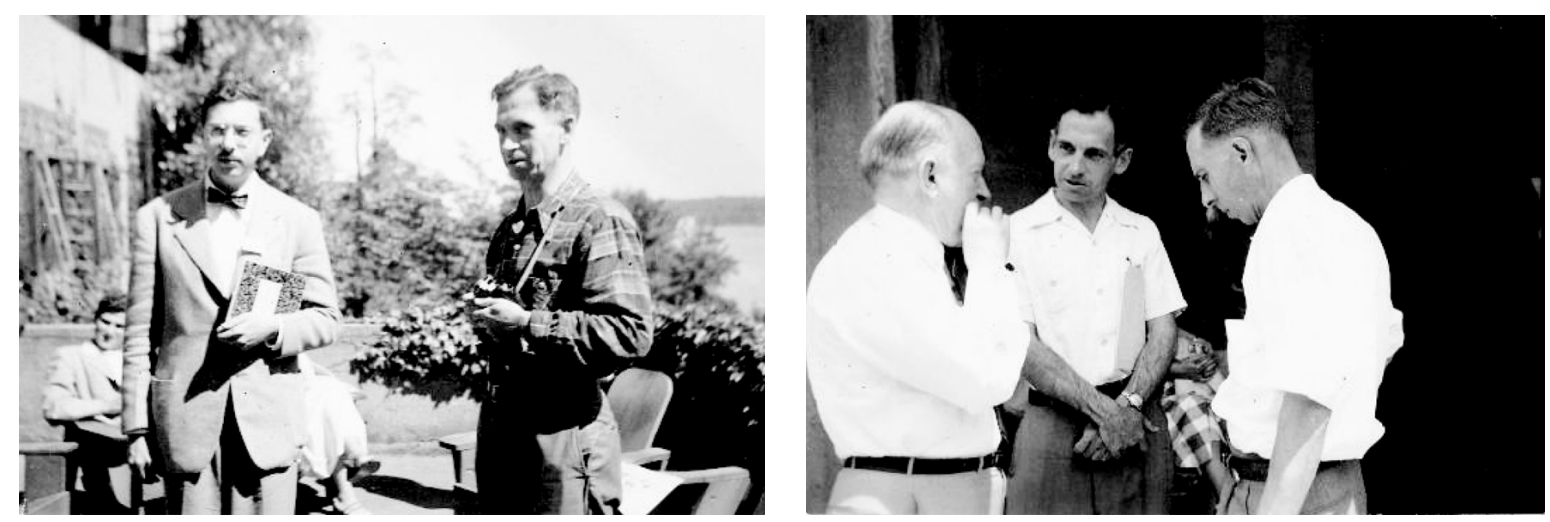

Figure 1. Clash of academic cultures. The CSH Symposium of 1950 brought the architects of the modern synthesis face-to-face with the anthropological community. It was this Symposium that moved the latter to adopt modern systematic practices and a populational view of human evolution. (Left to right) Stanley Garn (Michigan physical anthropologist), Ernst Mayr; George Gaylord Simpson, Mayr, Ted McCown (Berkeley physical anthropologist). Courtesy of Cold Spring Harbor Laboratory.

Symposium was crucial for hominid systematics. His studies had established high levels of within-species variation based on geographic, idiosyncratic, sexual, and ontogenetic factors in extant higher-primate species. In the transcribed discussions about his paper at the $\mathrm{CSH}$ Symposium, he stated, "It is the intra-populational variability of the anthropoids, however, which appears so impressively great to all students with access to large series of these primates" (Schultz 1951, p. 53). Dobzhansky commented in Schultz (1951, p. 52), "The finding by Professor Schultz of a great variability in some species of anthropoids is very important" (see Fig. 2).
By 1950, nearly 30 generic names and more than 100 specific names had been applied to hominid fossils. Washburn's CSH paper characterized hominid classification as being "in a complete state of confusion" (Washburn 1951, p. 67). Extant chimpanzees, by Schultz's count, had been bestowed 21 different generic names and 73 specific names.

As an antidote for such typological thinking about hominoid primates, at the CSH Symposium, Mayr collapsed the entire hominid fossil record into a single evolving lineage of genus Homo: “....all the now available evidence can be interpreted as indicating that, in spite of
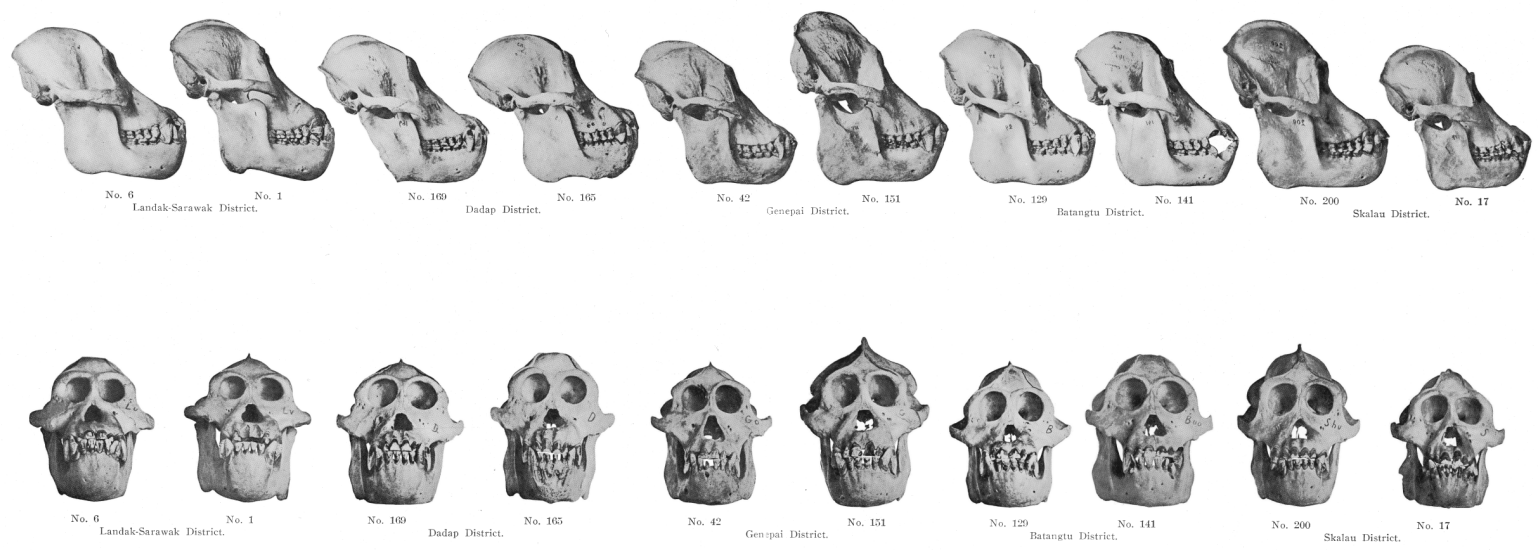

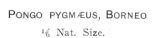

Figure 2. A key participant of the 1950 CSH Symposium was Adolph Schultz, who forcefully drew attention to normal natural intraspecific variation seen in modern hominoid primates. As ironically illustrated by this plate from Eliot's American Museum of Natural History three-volume set (1912), such variation can be considerable, as reflected in views of these skulls. All are modern orangutans, from one island (Borneo), adult, and male. Variation would only increase were geographic, ontogenetic, and sexual sources of variation to be included. Shape differences far less than those apparent here are currently being used to "diagnose" different "species" of fossil hominids, where yet another source of variation - temporal variation - is expected to increase variation even more than seen in this neontological series. If this osteological series were to be assessed by some modern techniques/practitioners blind to the species identity of the remains, the result would likely be a false inflation of actual biological species diversity. 
much geographical variation never more than one species of man existed on earth at any one time" (Mayr 1951, p. 112). He based his interpretation, at least in part, on ecological principles: "What is the cause for this puzzling trait of the hominid stock to stop speciating in spite of its eminent evolutionary success? It seems to me that the reason is man's great ecological diversity. Man has, so to speak, specialized into despecialization... . The ecological diversity of man and his slowness in acquiring reproductive isolating mechanisms have prevented the breaking up of Homo into several species" (Mayr 1951, pp. 116-117).

For his part, Simpson saw his CSH mission as teaching the principles of modern systematics (phylogenetics, classification) to an audience specialized on human evolution. He criticized the anthropologists for using the circular logic of "morphological dating," and was "... appalled at the extent of restoration indulged in by the anthropologists" (Simpson 1951, p. 57). Simpson joined Mayr and Dobzhansky in urging anthropologists and anatomists to use a modern biological species concept and the classificatory nomenclature consistent with it, instead of continuing the widespread practice of using genus and species nomina as convenient labels for fossil fragments.

The anthropologists and anatomists involved in the study of human evolution were thus pulled under the umbrella of the modern synthesis by its architects at the 1950 CSH Symposium. The gathering also witnessed full agreement on the importance of the fossil record for revealing human origins and evolution. A century earlier, Darwin had made important predictions about the historical data he predicted would one day be found in Africa. He had made extensive use of extant African apes to triangulate on still-missing human ancestors. This was appreciated by many participants at the $1950 \mathrm{CSH}$ Symposium. W.W. Howells wrote, "Darwin and Huxley proceeded of course from comparative anatomy... . Their allying of man and the apes was a great victory for the day. At the same time, however, men were men and apes were apes. The two could meet, all right, at a hypothetical crotch where their branches came together in the past. This is the diagram that has fascinated us, and plagued us, ever since. Added to this, the apes outnumbered us four to one which, with other facts, made us look like the aberrant animal, and the apes like the more natural, conservative primates" (Howells 1951, p. 80).

By 1950 , more than a century of fossil and primate behavioral discoveries had armed the architects of the modern synthesis with historical and neontological information unavailable to Darwin and Huxley, and had reinforced the mistaken notion that modern apes were suitable proxies for early hominids. Simpson, the paleontologist, was wary of this, noting that "non-historical seriation" of living forms "...may approximate, although it can never equal, a historical sequence" (Simpson 1951, p. 56). Co-organizer Sherwood Washburn concluded, "Without fossils, ancestors can be reconstructed only by what has been called mental triangulation... . The actual course of evolution can be determined only from fossils..." (Washburn 1951, p. 76).
Nine years later, the CSH Symposium centenary celebration of Darwin's Origin took a broader look at evolution. Not focused on humans as the 1950 gathering had been, it covered genetics, race, ecology, speciation, the fossil record, and evolutionary trends. Mayr's paper cited the "almost universal acceptance of the synthetic theory of evolution" (Mayr 1960). Simpson reviewed the entire Mammalia, but about hominids he said little: "Finally, from some lineage that probably separated in the early part of the pongid radiation developed a poorly known and apparently quite restricted radiation, probably mainly in the Pliocene, characterized especially by upright posture with bipedal terrestrial locomotion and later by exaggerated development of the brain. So few lineages are known that this may not have been a radiation, strictly speaking, but rather only progressive advance in a rather unified group. The surviving product is Homo and the grade is hominid" (Simpson 1960, p. 270).

\section{IN THE WAKE OF THE SYNTHESIS: 1950-1975}

Paleoanthropology witnessed relative systematic stability in the face of an expanding fossil record in the 30 years following the 1950 and 1959 CSH Symposia. Piltdown was exposed as a fraud in 1953. With it went most remaining objections to Australopithecus as a hominid. Washburn would convene the next conference on hominid systematics 12 years after the $1950 \mathrm{CSH}$ gathering. By then, Mayr had abandoned the null hypothesis of a single evolving hominid lineage, recognizing the "robust" Australopithecus from South Africa and the Leakeys' "nutcracker" cranium from Olduvai Gorge as a second hominid lineage. But that was as far as he would go: "When one reads the older anthropological literature with its rich proliferation of generic names, one has the impression of large numbers of species of fossil man and other hominids coexisting with each other. When these finds are properly placed into a multi-dimensional framework of space and time, the extreme rarity of the coexistence of two hominids became at once apparent" (Mayr 1963, p. 339).

During the 1960s and early 1970s, the evolutionary species concept was widely used within and beyond anthropology. As Tattersall and Schwartz (2009, p. 69) point out, anthropologists became "name shy." This stability was upset by the rise of parsimony cladistics and punctuationism (White 2009). The adoption of these by many practitioners of paleoanthropology represented an abandonment of the synthesis, which Tattersall has repeatedly and emphatically applauded.

The revealing of DNA's structure and the rise of molecular biology impacted human paleontologists, who first poorly received the immunologically based temporal estimates of chimp-human divergence of Sarich and Wilson (1967). Subsequent events have even emboldened some molecular biologists to have a hand at classification (Wildman et al. 2003). 


\section{THE RISE OF HOMINID DIVERSITY SYSTEMATICS: 1975-2009}

In his 1982 history of human paleontology, even as Mayr took another swipe at human paleontologists for being typological, he underestimated the degree to which the modern synthesis had been perturbed by the rise of cladistics and punctuated equilibria (White 2009). By this time, the evidentiary record of early hominids had been pushed more than a million years (Ma) deeper by the discovery of $A u$. afarensis in Ethiopia and Tanzania during the 1970s. Mayr assimilated this taxon as an earlier chronospecies of $\mathrm{Au}$. africanus.

The significance of $A u$. afarensis was the extension of the main attributes of its genus far deeper into the Pliocene. Evidence such as the 3.2-million-year-old A.L. 2881 ("Lucy") partial skeleton allowed human paleontologists to go beyond "mental triangulation" and to demonstrate that Darwin's inferences about the assembly sequence of human evolution (drawn on the basis of such triangulation, forced by the lack of a fossil record) had been wrong; bipedality and canine reduction had actually preceded lithic technology and brain expansion by millions of years.

By the mid 1970s, Stephen J. Gould's Natural History essays were widely read by the public and scholars alike. His 1976 article "Ladders and Bushes in Human Evolution" was inspired by Nature's publication of the $A u$. afarensis fossils at Laetoli. Gould asserted, "We are merely the surviving branch of a once luxuriant bush" (Gould 1976, p. 31). He even took the liberty of predicting when and what paleoanthropologists would find next: "We know about three coexisting branches of the human bush. I will be surprised if twice as many more are not discovered before the end of the century" (Gould 1976, p. 31).

Gould's 1976 prediction of bushiness became a paleoanthropological obsession in the years that followed, and modern practitioners and observers today have widely adopted an increasingly speciose, or "bushy," view of hominid phylogeny. The campaign to effectuate this was led by Gould, and Niles Eldredge and Ian Tattersall of the American Museum of Natural History. Quick to follow Gould's lead, they asserted in their 1982 The Myths of Human Evolution, "We have debunked the myth that evolutionary change is gradual and progressive" (Eldredge and Tattersall 1982, p. 175). This was a dramatic claim for any terrestrial vertebrate clade, let alone hominids. Tattersall and Eldredge sustained a persistent campaign of popular and professional writing. A recurrent theme was the heaping of abuse on their straw men of the modern synthesis, particularly its architects who dared to entertain the notion that phyletic (nonbranching) evolution might have characterized much of hominid evolution.

What motivated the campaign for what Eldredge has termed the "taxic" (as opposed to the transformational) approach to hominid paleobiology? Hominids have been used as exemplars ever since Darwin, so it is no wonder that the advocates of punctuationism and cladistics strove to accommodate this tiny but highly visible clade. And Tattersall and Eldredge were not the only front in the sustained war on the modern synthesis and its architects. As Cain (2009) contends, the breadth and persistence of
Gould's attacks on the paleontologist Simpson may well constitute a case of "ritual patricide."

Possible motives and connections aside, hominid diversity advocates have been very successful. With the deliberate maligning of the synthesis, a radically different environment for hominid paleobiology was structured. As diversity politics of the academy, mediaphilic journals, biology envy, new fossils from previously unplumbed periods, and the inevitable public interest inherent in hominid paleobiology were synthesized in the 1990s, it became evident that the simple 1960s would never return (White 2009). After a respite of nearly half a century since Cold Spring Harbor, it had become permissible, indeed fashionable, to split hominid fossils into multiple contemporary branches on a relatively bushy tree.

The regular pronouncements in Nature of correspondents and editors alike are but one measure of this diversity mania: "It thus appears that the phylogeny of hominids, like that of many other mammalian groups, is very bushy at its base" (see, e.g., Kappelman and Fleagle 1995, p. 559). In public displays such as the prominent and permanent new Hall of Human Origins at New York's American Museum of Natural History, the public views a bushy hominid tree with 23 named species and more than 10 clades. A recent book entitled The Last Human: A Guide to Twenty-two Species of Extinct Humans (Sawyer and Deak 2007) is available to navigate this maze.

In 2001, the cover of Nature featured a single cranium, and a new genus was created. Nature's "News and Views" author wrote, "We can now say with confidence that hominin evolution, like that of many other mammalian groups, occurred through a series of complex radiations, in which many new species evolve and diversify rapidly" (Lieberman 2001, p. 420). Gould's 2002 opus would use the same fossil as follows: "Multiple events of speciation now seem to operate as the primary drivers of human phylogeny" (Gould 2002, p. 909). These views of early hominid diversity have now been adopted so thoroughly that in the case of one prominent recent fossil discovery from Chad (Brunet et al. 2002), a reviewer attempted to rewrite the paper to accommodate this single cranium from the previously unsampled, $6 \mathrm{Ma}$ time horizon to his diversity viewpoint, because, after all, there must be other species "out there" waiting to be discovered. This is "X-files paleontology" (White 2000, 2009).

Tattersall heralded the discovery of this single Chadian cranium as follows: "From the beginning, the hominid pattern had been to diversify, and for multiple hominid species to be in existence at any one time" (see Tattersall and Schwartz 2009, p. 85 and reference to Tattersall 2000 cited therein). The biological reality of such assertions is questionable (White 2003, p. 1996).

Secondary sources, from prominent newspapers to the major scientific journals, have uncritically reported each new taxonomic pronouncement as reflecting ever more diversity. A recent review stated about the hominid clade, "Its evolution has been bushy or tree-like, not a progressive line leading inevitably to us. More than 20 species...have been identified from fossils... up to five different hominin species have coexisted" (Pagel 2009, p. 809). It also cites 
Tattersall. Today, Tattersall and his colleague Schwartz continue to promote hominid species diversity in popular books and scientific articles: "Yet the inescapable reality is that, with almost every new discovery, the rapidly expanding hominid fossil record amplifies the signal of past hominid diversity. As a result, pulled in opposite directions by received wisdom and by the accumulating morphological evidence, paleoanthropology is currently in a state of flux" (Tattersall and Schwartz 2009, p. 69). The reality may seem inescapable - to them - but a serious reality check seems to be in order.

\section{THE MIDDLE AWASH}

Paleoanthropology is often thought of as being driven by fossil data. As Mayr wrote in 1982 (p. 232), "Nothing, of course, has shed as much light on the history of the hominids as new fossil discoveries." Such discoverieswhile conditioned by theory and interpretation - do have evidentiary value independent of prevailing academic fashions.

Ethiopia's Afar Depression is a vast desert region at the junction of the Red Sea, Gulf of Aden, and continental African rifts. Had the H.M.S. Beagle sailed to explore this region on its return journey in 1836, Darwin's impact on biology might never have been felt. The region remained geographically unexplored by Europeans until well into the last century. Many of the earliest explorers to the region succumbed to intense temperatures and hostile inhabitants. Even today, the region is very difficult to investigate.

Late in the 1960s, exploration of the region by the French geologist Maurice Taieb revealed its rich geological, paleontological, and archaeological resources. Discovery of a partial skeleton at the Hadar site, now dated to 3.2 Ma, focused the world's attention here beginning in 1974.

The Middle Awash study area lies to the south of Hadar, is bounded by an escarpment at the base of the Ethiopian plateau to the west, and is today bisected by the modern Awash river (Gilbert and Asfaw 2008; Haile-Selassie and WoldeGabriel 2009). Our team has worked here since 1981, with the twin goals of conducting research and building local capacity in paleoanthropology. More than 70 Ph.D.-level scholars, spanning archaeology to zoology, have contributed. Nineteen nations have been represented, and more than 19,000 vertebrate fossils, nearly 2000 geological samples, and thousands of artifacts have been collected from a combined stratigraphic thickness of $\sim 1 \mathrm{~km}$ that spans the last 6 million years (Table 1). Figure 3 shows the geography and content of the study area and illustrates how the imperfections of the geological record continue to hamper our understanding of human evolution.

Discovery and analysis of Ardipitheus ramidus in the Middle Awash (White et al. 1994) and the geologically younger Australopithecus anamensis in Kenya (Leakey et al. 1995) during the 1990s established these as cladistic sister taxa. Their ages opened two possibilities. The null hypothesis is that these are chronospecies along one lineage (and in that sense, also "chronogenera"). Alternatively, the earlier taxon might be the dead-end, relict mother species of the younger genus. Only the discovery of more fossils would resolve this key problem in understanding mode and tempo in early hominid evolution. Unfortunately, the necessary temporal interval of the Middle Awash stratigraphic succession is marked by the incursion of a lake, in which fine fossils of a new fish species have been found (Murray and Stewart 1999), but no primates. One paleontologist's imperfection is another's bonanza, as we all celebrate the ever-narrowing gaps in the fossil record.

This example emphasizes that the mostly terrestrial, continental nature of the Middle Awash succession is better viewed as a series of sporadic snapshots than a continuous videotape of species through time (particularly hominids). But seen from a distance, here in this single Ethiopian valley, more than a dozen time-successive strata have yielded hominid fossils (along with stone tools after 2.5 Ma). Nearly 300 hominid individuals have been sampled across 6 million years. If hominid biodiversity was so high, it seems fair to ask whether there is evidence of it here. The answer is "no, not so far." Unlike many Plio-Pleistocene African assemblages in which two or sometimes (arguably) three hominid taxa are present, not one Middle Awash case demonstrates the presence of contemporary-let alone

Table 1. Main Discoveries in the Middle Awash Study Area, Afar Rift, Ethiopia

\begin{tabular}{llrlrl}
\hline $\begin{array}{c}\text { Age } \\
(\mathrm{Ma})\end{array}$ & Localities & $\begin{array}{c}\text { Faunal } \\
\text { NISP }\end{array}$ & Archaeology & $\begin{array}{c}\text { Hominid } \\
\text { NISP }\end{array}$ & $\begin{array}{l}\text { Hominid } \\
\text { publication }\end{array}$ \\
\hline 0.08 & Aduma & 21 & MSA & 3 & AJPA 03 \\
0.10 & Halibee & 2646 & MSA & 16 & \\
0.16 & Herto & 104 & MSA/late Acheulean & 12 & Nature 03 \\
0.2 & Talalak & 575 & MSA/late Acheulean & 2 & \\
0.5 & Bodo & 25 & typical Acheulean & 3 & Nature 84/Science 04 \\
1.0 & Bouri Daka & 753 & early Acheulean & 11 & Nature 02 \\
2.0 & Guneta & 753 & Olduwan+ & 2 & \\
2.5 & Bouri Hata & 576 & Olduwan & 11 & Nature 99 \\
3.5 & Maka & 171 & & 12 & Nature 84, 93 \\
3.9 & Belohdelie & 54 & & 1 & Nature 84 \\
4.1 & Asa Issie & 605 & & 37 & Nature 06 \\
4.4 & Aramis & 6432 & & 114 & Nature 94 \\
5.3 & Amba & 550 & & 1 & Nature 01 01 Nature 01/Science 04 \\
5.8 & Western Margin & 2230 & & 19 & Natur
\end{tabular}

NISP indicates numbers of identified specimens. Only major hominid announcements listed in publications. For more details, see text, Gilbert and Asfaw (2008), and Haile-Selassie and WoldeGabriel (2009). 


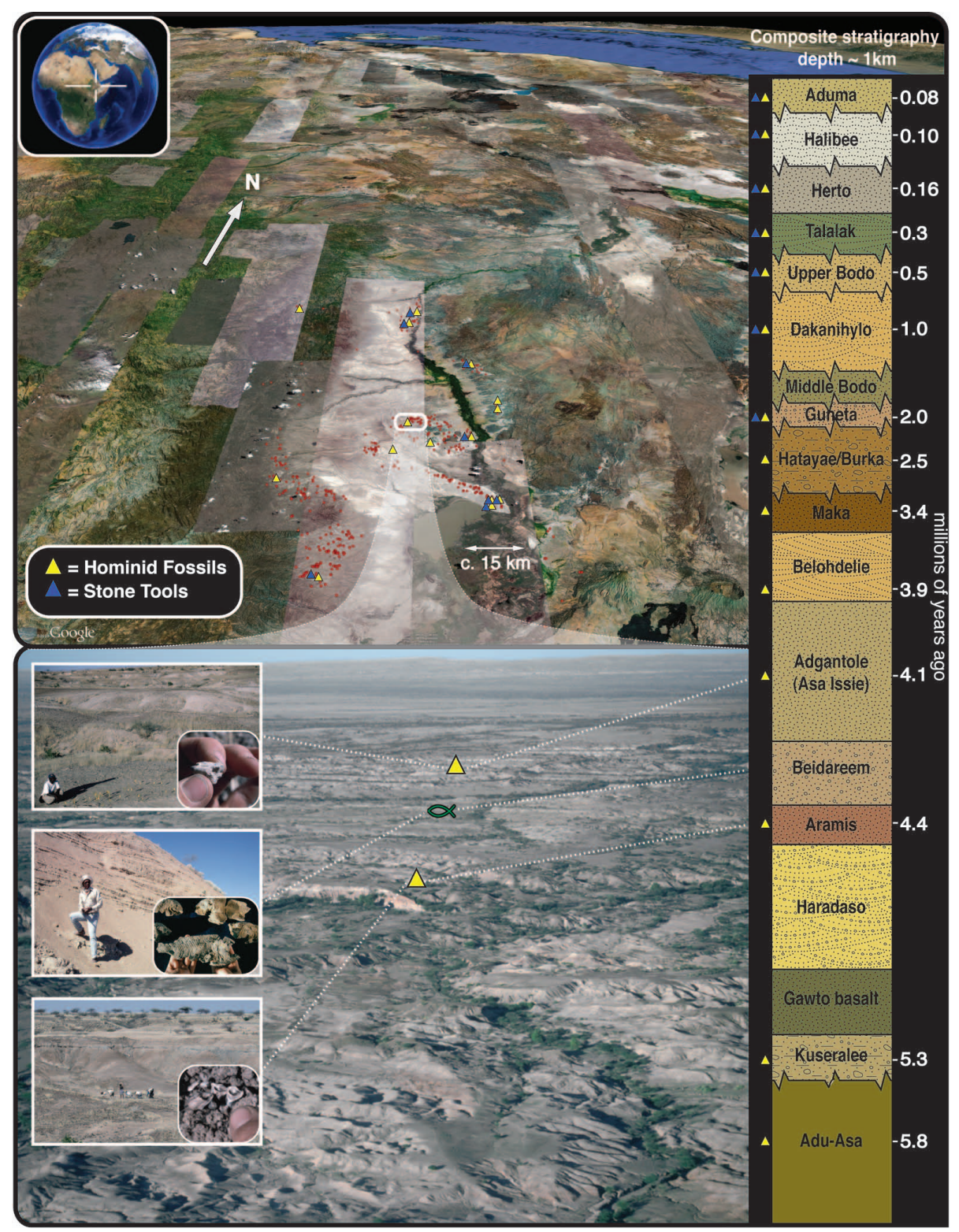

Figure 3. The Middle Awash paleoanthropological study area, Afar Rift, Ethiopia. View is to the north. A composite stratigraphic thickness of more than $1 \mathrm{~km}$ of predominantly fluviatile, lacustrine, and volcaniclastic sediment has sampled 14 different time horizons containing hominid fossils. Small red dots in the upper frame are geological sample points, usually indicating rocks extracted for radioisotopic, geomagnetic, isotopic, and sedimentological studies. Yellow triangles show the location of major hominid-bearing localities. Inset photographs show an antelope molar from the terrestrial 4.4 Ma Ardipithecus ramidus horizon, a new species of fish from the volcaniclastic lacustrine Beidareem horizon, and a molar attributed to Australopithecus anamensis from the overlying Adgantole Member. Even with a very thick $(>1 \mathrm{~km})$ succession, temporal, depositional, and facies-related gaps continue to make stratophenetics difficult for the many organisms fossilized in these rocks. See text for details.

sympatric — hominid species. The ghosts of CSH 1950 would not be surprised by these data.

\section{THE PRESENT THROUGH THE LENS OF CSH 1950}

Most current inventories tally around 25 separate named hominid species (Wood and Richmond 2000; Sawyer and Deak 2007). Figure 4 lists these and plots them chronologically. Since CSH 1950, it has been abundantly clear that there are several major sources of hominid "species diversity inflation." This inflation has been driven by Hennigian cladistics and the punctuationist advocacy of Gould and followers. Taxonomic inflation has been arrived at via the following practices, all recognized as problematic during the 1950 CSH Symposium:

- The bestowal of invalid names (invalid subjective synonyms) to contemporary specimens from single 
species. This practice has created a long species list for Hominidae. However, these biologically superfluous names only indicate improper systematic practice, often based on the failure to appreciate the extensive within-species variation that characterizes hominoid primates. Invalid names do not constitute evidence for branching speciation.

- The uncritical acceptance of arbitrary names that merely designate chronospecies (arbitrary segments) of species lineages. This practice also artificially lengthens the species list, but this is not evidence for biological species diversity. Chronospecies-based diversity inflation is not an issue for some phylogeneticists who refuse to recognize such parsing of apparently phyletic evolution: "No presumed separate, single, evolutionary lineage may be subdivided into a series of ancestral and descendant

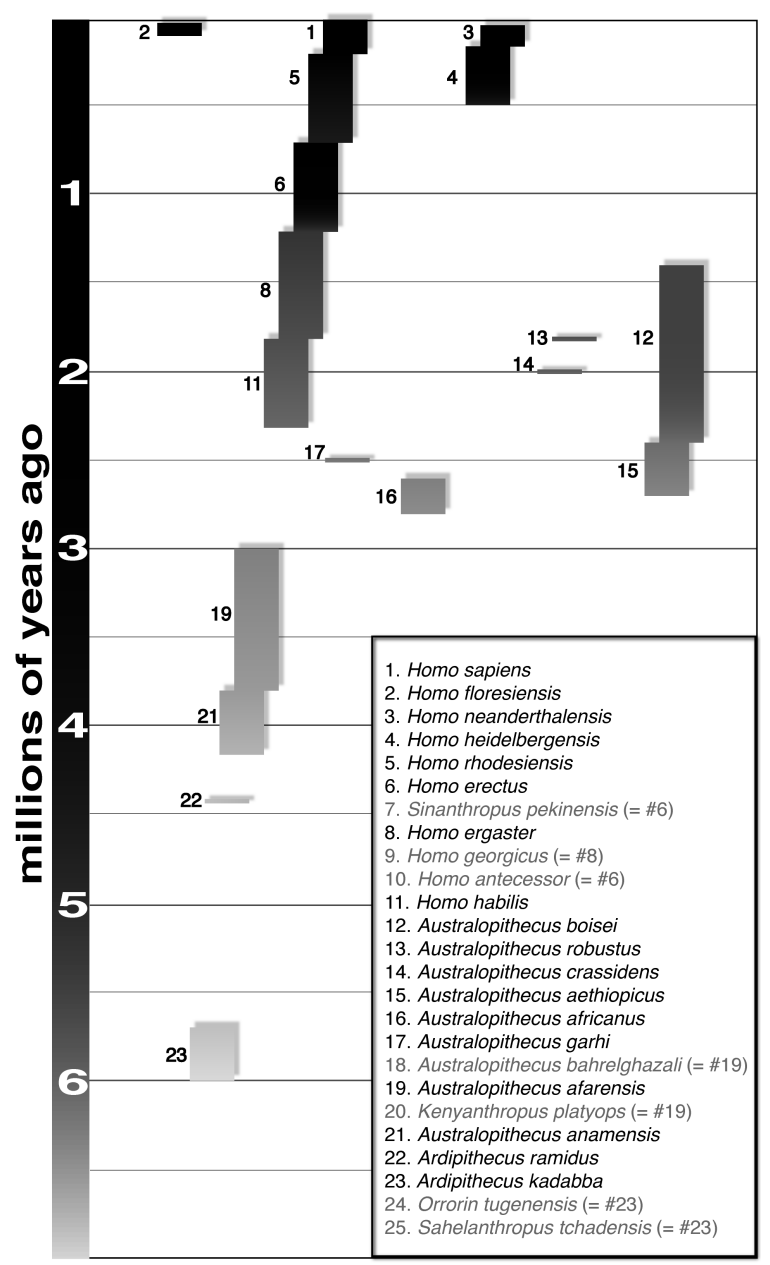

Figure 4. The synonomy, inferred phylogenetic relationships, and temporal distribution of 25 hominid species currently in wide use. Names in gray are considered to be junior subjective synonyms of previously established taxa. The first and last reliable appearance dates for the remaining taxa are plotted. Phyletic evolution between chronospecies is indicated by the abutting adjacent boxes. Note that the maximum number of separate species at any one time horizon is small, sampling only three or four lineages at $\sim 2 \mathrm{Ma}$. 'species"' (Wiley 1978, p. 21). It is ironic that if Wiley's admonition is applied to contemporary hominid trees, their diversity is considerably pruned (Fig. 4) (White 2009).

- The chronological exaggeration of species extinctions and/or first appearances. This practice has resulted in apparent temporal overlap among taxa that are actually time-successive (and therefore possibly sampling single evolving lineages). This erroneous time range extension should not be confused for actual biological species diversity. The proper measure of hominid species diversity through the Neogene should involve only the accurate delineation of species lineages at any given time horizon.

Once the 25+ modern hominid "species" are organized in realistic chronological and taxonomic space, an obvious pattern emerges (Fig. 4). It is remarkable how it conforms to predictions made at the 1950 CSH Symposium. This pattern continues to evoke the biological issue recognized by Dobzhansky so long ago, but since forgotten during the diversity mania described above. The question is not why there was so much hominid biological species diversity, but why - compared to other mammals - so little evolved within the hominid clade.

It is ironic, nearly 30 years after Eldredge and Tattersall's book (1982), and after such widespread acceptance of their "taxic" model of hominid evolution, that even today, any slice of geological time across Figure 4 intersects only a maximum or three or four hominid species lineages, and these are often geographically widely separated.

As Mayr, Simpson, Dobzhansky, and Schultz recognized in 1950, hominids were large terrestrial generalists. At least two species lineages specialized in intelligence and culture. Intelligence and culture increased the breadth of the niches occupied by these hominid species, further reducing opportunities for sympatry.

Gould's prediction about doubling the number of hominid lineages in a hominid "bush" was a bold one, but more than 30 years later, we still await evidence of a fourth (let alone a sixth) contemporary hominid lineage. So convinced was Gould by the taxic interpretations he had inspired, that by the time he published The Structure of Evolutionary Theory in 2002, the study of human evolution had, for him, been "recast" in "speciational terms" (Gould 2002, p. 910).

But how has Gould's 1976 prediction really done in the case of fossil hominids? If one measures species richness by the number of named taxa, the prediction has fared very well. But if one measures actual species diversity at any time slice, the prediction has not fared well, despite a great increase in discovered fossil specimens. Today, the record before us (Fig. 4) hardly constitutes a signal of adaptive radiation in the sense of contemporary biological science (Jolly 2001; Gavrilets and Losos 2009; Reznick and Ricklefs 2009; Schluter 2009).

Eldredge and Gould's work (1972 and thereafter) generated a large body of empirical evidence concerning what Simpson had called "quantum evolution" (punctuated equilibrium; see Cain 2009). Much of this has shown 
that rectangular evolution was more frequent in the record of life than had previously been recognized. In a long argument, Gould, Eldredge, and Tattersall have repeatedly deployed fossil hominid evidence in their attacks on the modern synthesis. They have persistently claimed that punctuational, cladogenetic species change has dominated in hominid evolution, as opposed to phyletic evolution. Ironically, the paucity of hominid lineages (as opposed to specimens) through geological time may actually turn out to be the exception that proves the rule among mammals. And ironically, the persistence of the chronospecies concept to describe what appears to be widespread phyletic evolution among hominids may even itself be evidence for the latter.

As Dobzhansky appreciated, there are good ecological and theoretical reasons to expect that all of this would be true. Indeed, studies of Neogene mammals have shown that generalists are predictably less speciose and have longer species durations (unless divided into chronospecies or invalid taxa) than specialists (Vrba 1993; Benton 2009). Culture-bearing hominids are consummate generalists, and the minimal hominid species diversity seen in the Pleistocene (notably the European Neanderthal clade) appears largely tied to the wide geographic spread of Homo erectus. The recent discovery of what may be a case of island dwarfing in Indonesia (Brown et al. 2004) may also be informative in this regard. If Homo floresiensis turns out (with the discovery of critically needed additional specimens) to be a separate hominid species, it would represent another exception to prove another rule, namely that hominids only speciate under very rare conditions (for a review of speciation, see Hendry [2009] and Schluter [2009]).

\section{CONCLUSIONS: CONSILIENCE AND FUTURE DIRECTIONS}

We all work on the neontological and paleontological results pertaining to a single tree of life whose primate species lineages - as Darwin surely recognized-virtually never anastomosed. Today, hominid paleobiology is probing at the root and branches of the hominid clade with a wide assortment of tools ranging from DNA sequencers to micro-CT scanners. Our interpretations must synthesize the data from those disparate activities. Major progress has recently been achieved. The 150-yearold debate about the place of Neanderthals and the origins of Homo sapiens has only recently abated in the face of breakthroughs in the paleontological (White et al. 2003) and neontological (biomolecular; Noonan et al. 2006; Briggs et al. 2009) realms.

Such consilience (Wilson 1998) shows the combinatorial power of the multidisciplinary approach. However, from Neanderthals on back, the prospects of similar recovery and analysis of ancient biomolecules are not good. Beyond the special case of a few Neanderthals, the DNA that created early hominids has all but disappeared. Darwin could never have predicted Australopithecus by triangulating between living chimpanzee and modern human anatomies and behaviors. Nor will it be possible to reveal the anatomy, habitats, or lifeways of our ancient ancestors by genomic triangulation or by more study of our relict ape relatives who have been independently evolving their own specializations for more than 6 million years.

The global experiment of human evolution cannot be repeated in a laboratory. We must infer what happened from the one-time experimental results, fragmentary and scattered as they may be. The good news about understanding our behavioral evolution is that there is a $2.5 \mathrm{Ma}$ archaeological record. The good news about understanding our anatomical evolution is that some of the tissues shaped by that disappeared DNA can still be recovered from unique paleontological records derived from ancient landscapes. The order in which our unique human characteristics have been assembled via evolution is susceptible to investigation, and the temporal and anatomical perspective of the fossil record will continue to be key to its success. Crucial in that investigation will be the understanding of how the hard tissues we recover as fossils were formed via development (see, e.g., Prabhakar et al. 2008). Integration will continue to be the key to better understanding human origins and evolution, just as it was during the CSH Symposium in 1950.

Huxley's Nature 1882 obituary said it well on the occasion of Charles Darwin's death: "He found a great truth, trodden under foot... ." A century and a half ago, Charles Darwin wrote in Origin (1959) only that "...light will be thrown on the origin of man and his history." He could not have imagined the illumination already thrown on our ancestry through the integration of ever-expanding constellations of evidence about our evolution. What wonders await our intellectual descendants at the Cold Spring Harbor Laboratory's bicentennial celebration of Darwin's great book?

\section{ACKNOWLEDGMENTS}

Thanks to the organizers of the 2009 CSH Symposium for a thoroughly stimulating, memorable, and enjoyable event. Thanks to all members of the Middle Awash research project for the field and laboratory work behind the summary presented here and to the Ethiopian and Afar Regional governments. Thanks to Josh Carlson, Kyle Brudvik, and Henry Gilbert for illustrations, editorial, and bibliographic work. Thanks to all others for their patience.

\section{REFERENCES}

Benton MJ. 2009. The red queen and the court jester: Species diversity and the role of biotic and abiotic factors through time. Science 323: 728-732.

Briggs A, Good JM, Green RE, Krause J, Maricic T, Stenzel U, Lalueza-Fox C, Rudan P, Brajković D, Kućan Ž, et al. 2009. Targeted retrieval and analysis of five Neandertal mtDNA genomes. Science 325: 318-321.

Brown P, Sutikna T, Morwood MJ, Soejono RP, Jatmiko, Saptomo EW, Due RA. 2004. A new small-bodied hominin from the Late Pleistocene of Flores, Indonesia. Nature 431: 1055-1061.

Browne J. 2002. Charles Darwin: A biography, Vol. 2. The Power of place. Knopf, New York.

Browne J. 2008. Essay: Birthdays to remember. Nature 456: 324-325. 
Brunet M, Guy F, Pilbeam D, Mackaye HT, Likius A, Ahounta $\mathrm{D}$, Beauvilain A, Blondel C, Bocherens $\mathrm{H}$, Boisserie J-R, et al. 2002. A new hominid from the Upper Miocene of Chad, Central Africa. Nature 418: 145-151.

Cain J. 2009. Ritual patricide: Why Stephen Jay Gould assassinated George Gaylord Simpson. In The palobiological revolution: Essays on the growth of modern paleontology (ed. D Sepkoski and M Ruse), pp. 346-363. University of Chicago Press, Chicago.

Darwin C. 1859. On the origin of species by means of natural selection, 1 st ed. Murray, London.

Darwin C. 1871. The descent of man, and selection in relation to sex. Murray, London.

Delisle RG. 2006. Debating humankind's place in nature, 1860 2000. Pearson/Prentice Hall, Upper Saddle River, NJ.

Dobzhansky T. 1944. On species and races of living and fossil man. Am J Phys Anthropol 2: 251-265.

Eldredge N, Gould SJ. 1972. Punctuated equilibria: An alternative to phyletic gradualism. In Models in paleobiology (ed. TJM Schopf), pp. 82-115. Freeman, Cooper, San Francisco.

Eldredge N, Tattersall I. 1982. The myths of human evolution. Columbia University Press, New York.

Elliot DG. 1912. A review of the Primates: Anthropoidea, Vol. 3. American Museum of Natural History, New York.

Gavrilets S, Losos JB. 2009. Adaptive radiation: Contrasting theory with data. Science 323: 732-737.

Gilbert WH, Asfaw B, Eds. 2008. Homo erectus: Pleistocene evidence from the Middle Awash, Ethiopia. University of California Press, Berkeley.

Gould SJ. 1976. Ladders, bushes, and human evolution. Nat Hist Mag 85: 24-31.

Gould SJ. 2002. The structure of evolutionary theory. Belknap, Cambridge, MA.

Haile-Selassie Y, WoldeGabriel G, Eds. 2009. Ardipithecus kadabba: Late Miocene evidence from the Middle Awash, Ethiopia. University of California Press, Berkeley.

Hendry AP. 2009. Speciation. Nature 458: 162-164.

Hong J-W, Hendrix DA, Levine MS. 2008. Shadow enhancers as a source of evolutionary novelty. Science 321: 1314.

Howells WW. 1951. Origin of the human stock: Concluding remarks of the chairman. Cold Spring Harbor Symp Quant Biol 15: 79-86.

Huxley TH. 1863. Man's place in nature. Williams and Norgate, London.

Huxley TH. 1882. Charles Darwin. Nature 25: 597.

Huxley J. 1942. Evolution: The modern synthesis (1964 edition). Wiley, New York.

Jolly CJ. 2001. A proper study for mankind: Analogies from the papionin monkeys and their implications for human evolution. Yearb Phys Anthropol 44: 177-204.

Kappelman J, Fleagle JG. 1995. Age of early hominids. Nature 376: $558-559$.

Leakey MG, Feibel CS, McDougall I, Walker A. 1995. New four-million-year-old hominid species from Kanapoi and Allia Bay, Kenya. Nature 376: 565-571.

Leakey MG, Spoor F, Brown FH, Gathogo PN, Kiarie C, Leakey LN, McDougall I. 2001. New hominin genus from eastern Africa shows diverse middle Pliocene lineages. Nature 410: 433-440.

Lieberman DE. 2001. Another face in our family tree. Nature 410: 419-420.

Marques-Bonet T, Kidd JM, Ventura M, Graves TA, Cheung Z, Hiller LW, Jiang Z, Baker C, Malfavon-Borja R, Fulton LA, et al. 2009. A burst of segmental duplications in the genome of the African great ape ancestor. Nature 457: 877-881.

Mayr E. 1951. Taxonomic categories in fossil hominids. Cold Spring Harbor Symp Quant Biol 15: 109-118.

Mayr E. 1960. Where are we? Cold Spring Harbor Symp Quant Biol 24: 409-440.

Mayr E. 1963. The taxonomic evaluation of fossil hominids. Classification and human evolution. Viking Fund Publ Anthropol 37: 332-345.

Mayr E. 1982. Reflections on human paleontology. In A history of
American physical anthropology 1930-1982 (ed. F Spencer), pp. 231-237. Academic, New York.

Murray AM, Stewart KM. 1999. A new species of tilapiine cichlid from the Pliocene, Middle Awash, Ethiopia. J Vertebr Paleontol 19: 293-301.

Noonan JP, Coop G, Kudaravalli S, Smith D, Krause J, Alessi J, Chen F, Platt D, Pääbo A, Pritchard JK, Rubin E. 2006. Sequencing and analysis of Neanderthal genomic mtDNA. Science 314: 1113-1118.

Pagel M. 2009. Natural selection 150 years on. Nature 457: 808 811.

Pinker S. 2003. Language as an adaptation to the cognitive niche. In Language evolution: The states of the art (ed. MH Christiansen and S Kirby), pp. 16-37. Oxford University Press, Oxford.

Prabhakar S, Visel A, Akiyama JA, Shoukry M, Lewis KD, Holt A, Plajzer-Frick I, Morrison H, FitzPatrick DR, Afzal V, et al. 2008. Human-specific gain of function in a developmental enhancer. Science 321: 1346-1349.

Reznick DN, Ricklefs RE. 2009. Darwin's bridge between microevolution and macroevolution. Nature 457: 837-842.

Sarich VM, Wilson AC. 1967. Immunological time scale for hominid evolution. Science 158: 1200-1203.

Sawyer GJ, Deak V. 2007. The last human: A guide to twenty-two species of extinct humans. Nèvraumont, New York.

Schluter D. 2009. Evidence for ecological speciation and its alternative. Science 323: 737-741.

Schultz, A. 1951. The specializations of man and his place among the catarrhine primates. Cold Spring Harbor Symp Quant Biol 15: 37-53.

Sepkoski D, Ruse M, Eds. 2009. Introduction: Paleontology at the high table. In The palobiological revolution: Essays on the growth of modern paleontology, pp. 1-13. University of Chicago Press, Chicago.

Simpson GG. 1951. Some principles of historical biology bearing on human origins. Cold Spring Harbor Symp Quant Biol 15: 55-66.

Simpson GG. 1960. The nature and origin of supraspecific taxa. Cold Spring Harbor Symp Quant Biol 24: 255-271.

Tattersall I. 2000. Once we were not alone. Sci Am 282: 56-62.

Tattersall I, Schwartz J. 2009. Evolution of the genus Homo. Annu Rev Earth Planetary Sci 37: 67-92.

Vrba ES. 1993. Turnover-pulses, the Red Queen, and related topics. Am J Sci 293: 418-452.

Washburn S. 1951. The analysis of primate evolution with particular reference to the origin of man. Cold Spring Harbor Symp Quant Biol 15: 67-78.

White TD. 2000. A view on the science: Physical anthropology at the millennium. Am J Phys Anthropol 113: 287-292.

White TD. 2003. Early hominids: Diversity or distortion? Science 299: 1994-1996.

White TD. 2009. Ladders, bushes, punctuations, and clades: Hominid paleobiology in the late twentieth century. In The Palobiological revolution: Essays on the growth of modern paleontology (ed. D Sepkoski and M Ruse), pp. 122-148, University of Chicago Press, Chicago.

White TD, Suwa G, Asfaw B. 1994. Australopithecus ramidus, a new species of early hominid from Aramis, Ethiopia. Nature 371: 306-312.

White TD, Asfaw B, DeGusta D, Gilbert H, Richards GD, Suwa G, Howell FC. 2003. Pleistocene Homo sapiens from Middle Awash, Ethiopia. Nature 423: 742-747.

Wildman DE, Uddin M, Liu G, Grossman LI, Goodman M. 2003. Implications of natural selection in shaping $99.4 \%$ nonsynonymous DNA identity between humans and chimpanzees: Enlarging genus Homo. Proc Natl Acad Sci 100: 71817188 .

Wiley EO. 1978. The evolutionary species concept reconsidered. Syst Zool 27: 17-26.

Wilson EO. 1998. Consilience: The unity of knowledge. Knopf, New York.

Wood BA, Richmond BG. 2000. Human evolution: Taxonomy and paleobiology. J Anat 196: 19-60. 


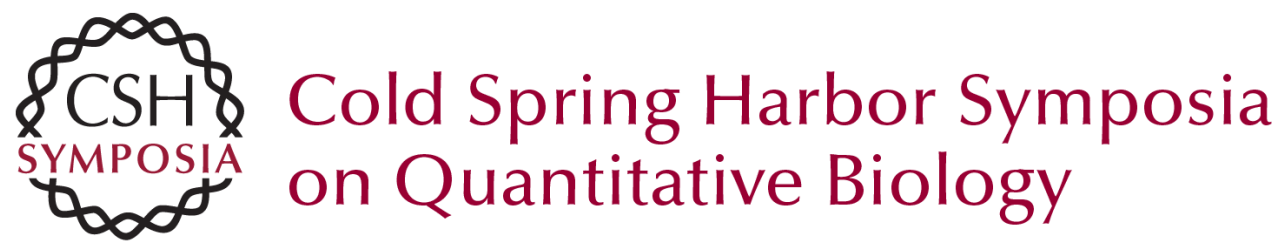

\section{Human Origins and Evolution: Cold Spring Harbor, Déjà Vu}

T.D. White

Cold Spring Harb Symp Quant Biol 2009 74: 335-344 originally published online September 23, 2009 Access the most recent version at doi:10.1101/sqb.2009.74.016

References This article cites 42 articles, 11 of which can be accessed free at: http://symposium.cshlp.org/content/74/335.full.html\#ref-list-1

License

Email Alerting Receive free email alerts when new articles cite this article - sign up in the box at the Service top right corner of the article or click here.

To subscribe to Cold Spring Harbor Symposia on Quantitative Biology go to:

http://symposium.cshlp.org/subscriptions 